Article

\title{
Becoming Monument, Activating Windsor
}

\section{Karen Engle}

School for Arts and Creative Innovation, University of Windsor, 401 Sunset Avenue, Windsor N9B 3P4, Ontario, Canada; E-Mail: kengle@uwindsor.ca; Tel.: +1-519-962-3809; Fax: +1-519-971-3614

Received: 22 October 2013; in revised form: 18 November 2013 / Accepted: 18 November 2013 / Published: 27 November 2013

\begin{abstract}
What does it mean to live in a dying place? This auto-critical article asks this question in the context of the Windsor/Detroit region, one of the most economically depressed zones in North America. Using the work of Barthes, Benjamin, and Taussig, I ruminate on the psycho-somatic experiences of trying to navigate a world that most writers have already dismissed as haunted and abandoned.
\end{abstract}

Keywords: Benjamin; cultural theory; cities

When you drive into Windsor, Ontario, from the 401, it looks like a real city. There's a downtown skyline-giant 1970s towers of shimmering glass dwarfing other, more historic skyscrapers. As you pull into Windsor proper, however, you find that this skyline doesn't belong to Windsor: it actually sits across the river in another country. It's the edge of Detroit. Yet, for all intents and purposes, this skyline has served as Windsor's economic center for decades. In Windsor, Detroit is what you look at, but it's not where you are. The real downtown - the downtown that looks real-is across the river. Windsor is the only geographic point in Canada technically south of the US. When you look at Detroit, you're looking north.

Windsor was supposed to be temporary: a rest stop. It is, after all, a border town. People come in order to go. The year I was hired by the University, three other women were hired as well. Women focused with plans and with projects—none of which involved sticking around here. They've all left now, having been more successful at getting other jobs in places they wanted to live. When a fourth colleague left two years ago, she gave me a mano cornuto in red plastic, a devil's horn meant to protect against malocchio - the evil eye. She looked at me hard and said: "Promise me you won't die here, Karen. Just don’t die here.” I dangled my new red horn and I promised her, but as I detailed my thin 
and flickering plans for exit, trying to thicken them up with bravado, with false confidence, the anxiety fibers inside of me woke up and fired: you'll die here you'll die here you'll die here you'll die here...

I have lived across the river from Detroit for seven years. For seven years, I have tried, and failed, to leave this dirty, broke, emptied-out factory town where unemployment consistently ranks at the top of the national charts. Convinced I had no place here, I sought to float above it, to hover in a kind of stasis chamber until cleared for departure. However, the body shuts down in stasis. In the sleeping pods of Ridley Scott's Alien, existence is reduced to bare life [2]. The crew bodies in hypersleep become mere systems in need of monitoring; they lose all self-sustaining capacity, all cognitive function. The ship-Nostromo-becomes the source of life and the pods relay its power into the sleeping meat, thereby creating a nervous system in which human bodies are extremities in a much larger machine network.

In hypersleep, bodies lose their specificity, that particular quality writers have variously named individuality, subjectivity, agency, or singularity. I've been stripped down to basic organ function in this floating chamber, and in my effort to become impermeable, to remain untouched by this place, I have also arrested the flow of ideas, the current of imagination. My intellectual world has thinned out like Simmel's metropolis, where money causes things to lose their qualities, and they all "float with the same specific gravity” in the greying out world of capital ([3], p. 330). As I flicker in and out of selfhood, I feel increasingly restless. There's a perpetual nervousness in my belly. It's a low-level vibration, like the "Windsor Hum", a mysterious low frequency droning that cycles underground. ${ }^{1}$ Researchers think the Hum stems from the re-opening of a U.S. Steel ironworks mill on Zug Island, an industrialized peninsula on the U.S. side of the Detroit River. ${ }^{2}$ The Windsor Hum offers a lesson in connectivity - in the essential relationality of things - and in the precariousness of systems. To a large extent, Taussig's fascination with the nervous system stems from these two qualities: "Even while it inspires confidence in the physical centerfold of our worldly existence-at least that such a centerfold truly exists - and as such bespeaks control, hierarchy, and intelligence-it is also...somewhat unsettling to be centered on something so fragile, so determinedly other, so nervous” ([5], p. 2). Zug Island sends out shock waves, underwater and underground, and now-for those who hear it — these waves rattle people's beds and disturb their equanimity. ${ }^{3}$

Things come and go here. The city is filled with empty storefronts and For Lease signs. When I moved from a booming Alberta oil economy, everyone I met outside the University asked why come here since everyone here was going there. In Windsor, it was strip clubs and bars that boomed. At one point, we had more strip clubs per capita than any city in Canada. Kids from Detroit would cross the border on weekends to party since Ontario's drinking age is nineteen, but that was before the new passport regulations came into effect, and before the smoking ban. Now even the downtown bars are on life support.

For years I thought that I couldn't write about a place like Windsor because it didn't have the "shock-effect" that Simmel describes as fundamental to the metropolitan experience. It didn't seem like a real city, the teeming metropolises I imagine when reading Simmel and Benjamin. For Simmel,

\footnotetext{
Similar hums have been detected in other cities around the world.

For an audio sample of the Windsor Hum, see: [4].

See: [6].
} 
the city-dweller is daily threatened by a million spears of stimuli: shocks of sound, people, smells, machines, and advertisements. In order to survive, the metropolitan erects a force field in order to fend off the threat of being overwhelmed by the outside. The city-dweller becomes blasé, an expert at ignoring the type of world I associate with Tokyo or New York. However, the world Simmel actually describes is muffled and de-saturated, not in actuality, but in the experience of the blasé inhabitant: "the meaning and value of the distinctions between things, and therewith of the things themselves, are experienced as meaningless. They appear to the blasé person in a homogenous, flat and gray color with no one of them being preferred to another” ([3], p. 330). For Simmel, a city is defined less by its demographics than by its innervations into inhabitants. Cities are not simply external entities defined by physical structure and population size. They extend beyond themselves; they invade us as we invade them. I realize now that a city can penetrate without consent, and that my floating chamber has never been self-regulating or self-sustaining: shockwaves have been breaching it this whole time, re-wiring my connections in the process.

In Empire of Signs, Roland Barthes attempts a description of Tokyo. Not of Tokyo the actual city, but of its shattering effect on the author. The purpose in this set of writings is to trace, somehow, a situation in which interpretation is useless, in which difference remains irreducible - in contrast to the activity of centuries of Western writings on the Orient - and consequently, to disturb the system of the symbolic. Japan is not a code to break, but an opening on to "the very fissure of the symbolic" ([7], p. 4). The impact of this kind of anti-hermeneutic writing is tectonic: "knowledge, or the subject...vacillate" ([7], p. 4). Tokyo's central core provides a key example. For Barthes' author, the traditional concentric organization of Western cities emerges from a long-standing philosophical association of the center with presence: "in accord with the very movement of Western metaphysics, for which every center is the site of a truth, the center of our cities is always full: a marked site, it is here that the values of civilization are gathered and condensed...to go downtown or to the center-city is to encounter the social 'truth', to participate in the proud plenitude of 'reality'” ([7], p. 30). Tokyo, by contrast, is structured around the emperor's Imperial Palace, a private residence protected from all access, both visual and physical. It is an unseen center, a deeply structured privacy built into the most public of places. To echo Yeats, the center in this arrangement, cannot hold: ${ }^{4}$

One of the two most powerful cities of modernity is thereby built around an opaque ring of walls, streams, roofs, and trees whose own center is no more than an evaporated notion, subsisting here, not in order to irradiate power, but to give to the entire urban movement the support of its central emptiness the system of the imaginary is spread circularly, by detours and returns the length of an empty subject ([7], p. 32).

Whereas the Western center pulses life through its commercial activity, Tokyo's nervous system runs on empty. In Windsor hotel rooms, guidebooks point the traveler to destinations outside the city. The city advertises itself as a place to leave.

Empire of Signs is not a work of sociology or political economy. Barthes has not researched in any conventionally academic way the material he presents; Japan is not an anthropological object. The author claims, in fact, to objectify himself through this text and he describes this experience in photographic terms: “The author has never, in any sense, photographed Japan. Rather, he has done the

4 See “The Second Coming” ([8], p. 158). 
opposite: Japan has starred him with any number of 'flashes'; or, better still, Japan has afforded him a situation of writing” ([7], p. 4). Writing and the freeze-frame of the flash are identical here, each isolating a scene and encasing it, whether in ink or in film, for others to see. Yet, subject and object are not simply inverted, for Japan — or an idea of Japan as Zen, as elegant, as wholly Other-is objectified, even as it eludes the reader and refuses systematic classification. As terms, subject and object seem to come in and out of focus. Not emptied out and left for dead, but definitely flickering and humming, like fluorescent lights on the brink of burning out. The flickering jolts Barthes' author in and out of himself. He has visions like those hospital patients who die and then come back, talking of light and peace and another mode of being.

But all this sounds like so much nonsense to a good child of the Enlightenment, and I am nothing if not a good child of the Enlightenment. As Barthes' author seeks to describe an alien dreamworld using the language of this world, I read and am torn in two: seduced, on the one hand, by the beauty and emptiness of that other world, I am simultaneously made nervous by this seduction. So, like that old Freudian game of fort/da, I shuttle myself back and forth between immersion and suspicion of Barthes' text, looking for meaning that I've already been told does not exist. As I stand back and watch my shuttling (we are falling into the first of many mise-en-abîmes), I suddenly realize that Barthes' author has, through sleight of hand, turned me into a psycho-geographic traveler. Moving in and out of reason, back and forth from my own metaphysics of presence, I see how Barthes' Empire of Signs has short-circuited my thinking system and jolted me into a different way of seeing Windsor. Windsor, in other words, is my Empire of Signs: by holding me in thrall and all unhinged, it has afforded me a “situation of writing” ([7], p. 4). Suddenly, Tokyo is much closer than Detroit.

There's something nerve-wracking about being stuck in a place meant for passing through, a place that can only point outside itself like a wormhole. I feel this most acutely when traffic backs up in the tunnel under the Detroit River and I'm brought to a forced arrest in this leaking underworld. Constipation as incarceration: cars jammed up as far as you can see, in front and behind, all waiting for passage from one country to the next. How long before this tunnel collapses under the weight of all that water flowing overhead? If I'm on the Detroit side when it buckles, will the Canadians ignore me? I moved to Windsor the same way I descend, over and over again, into this tunnel: believing I'll be able to get out. Instead, all I see when the traffic starts to move again are more border guards.

When Barthes calls the situation of Tokyo a fissure, I wonder: was he thinking in corporeal terms or merely existential ones? "Fissure" designates a split, of course, but in medicine, fissures are tears or grooves in the body. Naturally occurring ones exist, like Broca's fissure in the brain, but fissures can also be abnormal, caused by injury or prolonged muscular tension. The latter category compromises the health of the system, causing pain, bleeding, and infection. Fissures can show up anywhere, from teeth to lung to anus, and the invasive ones hurt. If Japan is an opening "on to the very fissure of the symbolic", this means that the system of language is split. Barthes' author is referring, of course, to what theory types have long-since named the linguistic turn, the recognition that language is not straight or transparent or consistent. Many writers have also noted the violence of the Western symbolic and the wounding capacity of language. But the materiality of Barthes' fissure strikes me as peculiar because the etiology is uncertain: is it a natural fissure — a groove built into the system itself_-or an accidental and infected rip? What if it's both: a natural fissure that bleeds red and leaks yellow and can't be fixed? 
Detroit has gone supernova in the last decade, abstracted out to symbolize a series of deaths. It has emerged as the ultimate ghost town, comprising both the ground zero of the failing US auto industry, and the site of an urban decline so marked that it has come to stand for the sign of the end of the American century. In the last several years, journalists, artists, and, increasingly, scholars, feel compelled to document the goings-on in Detroit. ${ }^{5}$ In addition to the usual stories of violence, poverty, racism, and urban blight, there are also stories of survival and hope. Urban farming initiatives and art collectives, for instance, currently feature as indications that some sort of a future is gestating in the city. The return of beavers to the area serves alternately as evidence that life is returning there, and that life is dying there. Detroit seems the perfect backdrop for ghost stories.

Hanging off the edge of Canada and looking north across the water, I stand in the shadow of a ghost. From here, I can see journalists and artists pecking at its corpse like vultures. More than one senior academic has told me that Detroit is ripe for the picking-a real career-maker if I want it. But I'm nervous about jumping over there. Border guards patrol the river, and who knows what's in that water anyway. I keep thinking about Latour's admonishments against jumping, and the connecting wires in Taussig's Nervous System. ${ }^{6}$ Even more, I remember Benjamin's contention that “[o]vercoming the concept of 'progress' and overcoming the concept of "period of decline” are two sides of one and the same thing” ([16], p. 460). Decline and rebirth are easy terms to throw around, but eschatology and resurrection are magical abstractions; I can't lay hold of them for a closer look because they keep eluding my grasp, like fireflies in a Windsor summer. I keep thinking that if I want to avoid falling into mythologizing and allegorizing, I have to begin by acknowledging that the only reason I can see Detroit is because I live in Windsor: the place Detroit sees when it looks south. The place I dream of leaving, just not by falling.

In Windsor's downtown, post-1950s architectural banality is juxtaposed against those historic bank buildings you find in every small town across the country. No towering pools of shimmering glass and steel, no throbbing central core. Sitting at the top of Ouellette Avenue, Windsor's Main Street, a fourteen storey Bank of Commerce building and a fourteen storey Chrysler building look across the river at the Penobscot, Fisher, Guardian, and One Detroit Center buildings. It's quite a view. It's what everyone comes down here to see. I came down to the riverfront just the other day to photograph the scene so I could confirm my memory of the Detroit skyline, and as I walked down the concrete path to the river's edge, I heard an engine directly behind me. I turned and saw a gold Alfa Romeo idling no more than five feet away.

It was a classic Giulietta Sprint, sunlight glaring off its windshield, its tensed and cat-like steel ready to pounce. I moved aside and it slid in between the bike path and pedestrian walkway, and powered down. The plates were from Florida, and so was the couple that emerged from its interior. The driver asked me to photograph he and his wife in front of the "Ren Center" across the river-GM's headquarters, officially named the Renaissance Center-and to center the car in the picture. The woman's sunglasses were rimmed in pink plastic, and the sun bounced off them like it did off the

\footnotetext{
See, for example: [9-14].

6 In his critique of the local/global framework, Latour writes: “when you put some local site 'inside’ a larger framework, you are forced to jump. There is now a yawning break between what encloses and what is enclosed, between the more local and the more global. What would happen if we forbade any breaking or tearing and allowed only bending, stretching, and squeezing?” ([15], p. 73).
} 
windshield. They were heading to California next, to the Alfa Romeo convention, and they needed this photograph for the convention. They needed Detroit as a backdrop for Giulietta's gleaming body. I looked through the viewfinder and thought of F.T. Marinetti's fantasy of a metallized human, fast and sleek like an automobile, in his first Futurist Manifesto [17]. I thought of this car-body speeding through the night while Marinetti proclaimed death to libraries and history and women, and praised war as "the world's only hygiene". I looked through the viewfinder and saw a man and a woman and a car standing against a city haunted by its relation to the automobile, and I wondered whether Marinetti would burn down Detroit too. As the shutter clicked, I saw Detroit become a monument: the perfect backdrop for pictures.

Monuments, as Robert Musil observed, are strange objects. Erected in public places in order to be seen, their fate is one of paradoxical invisibility: "Aside from the fact that you never know whether to refer to them as monuments or memorials, monuments do have all kinds of other characteristics. The most salient of these is a bit contradictory; namely, that monuments are so conspicuously inconspicuous. There is nothing in this world as invisible as a monument” ([18], p. 64). Curiously, Musil imbues the monument with a special substance for warding off attention; it's not passersby who refuse to acknowledge a monument, it's the monument that defies observation: "Doubtless they have been erected to be seen — even to attract attention: yet at the same time something has impregnated them against attention. Like a drop of water on an oilskin, attention runs down them without stopping for a moment. We cannot say that we do not notice them. We should say that they de-notice us...” ([18], p. 64). We can make Detroit symbolize whatever we like, detach it from history the way commemorative monuments are always situated out of context. The city just stands there. Encased in a kind of force field that shields it from all this attention, Detroit ignores us.

I returned the camera and began the walk back up to the top of Ouellette. In Windsor, they pronounce it O-let, dropping the French from the picture in the same way that Pierre Street is Peeree, Langlois is Langloy, and Pelissier is Pelisher. As the Giulietta passed me on its way to California, I wondered what Detroit saw when it looked across the river. I decided to take some photographs of Windsor from the same place I had shot Detroit: the top of O-let. The sun was blinding, and I had to get out of the light in order to see the picture. Back home, I watched the image load on my computer screen. I felt a jolt of recognition. The Chrysler building and the Bank of Commerce building were locked in a permanent face-off with each other. A single lamppost was thrusting into space between them (Figure 1).

Figure 1. Monumental Windsor.

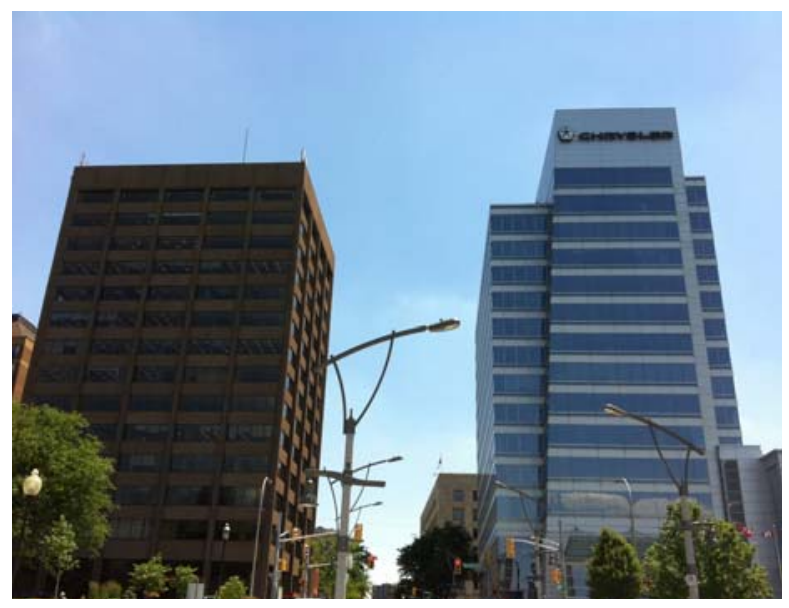


The scene brought me back to a much earlier face-off between the German and the Soviet monuments at the 1937 Paris Exposition (Figure 2).

Figure 2. La tour Eiffel en 1937.

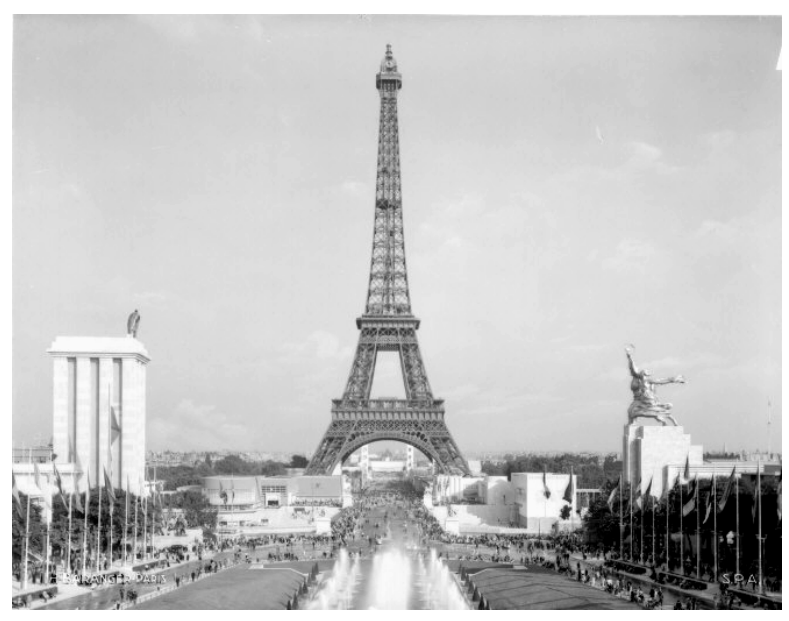

Made two years before the Eastern Front showdown between these superpowers, and three years before Paris was literally taken over by the Occupation, the Exposition photograph sets up the battleground for Derrida's haunting future anterior-a glimmer of what will have been [19]. Albert Speer, architect for the German pavilion, saw his design as a visual blockade against Boris Iofan and Vera Mukhina's Soviet representation of Communist power. ${ }^{7}$ Situated in the shadow of these monoliths, the tiny Spanish Pavilion stood up against fascism and displayed, for the first time ever, Picasso's Guernica.

Although the scale is different—-the Eiffel Tower returns as a lamppost in my photograph—Paris is leeching into Windsor. In the Berlin Chronicle, Benjamin describes the shock of memory in distinctly photographic terms. Observing the strange phenomenon whereby one can forget a room in which one has spent years, Benjamin writes:

...one day from an alien source it flashes as if from burning magnesium powder, and now a snapshot transfixes the room's image on the plate. It is we ourselves, however, who are always standing at the center of these rare images. Nor is this very mysterious, since such moments of sudden illumination are at the same time moments when we separated from ourselves, and while our waking, habitual, everyday self is involved actively or passively in what is happening, our deeper self rests in another place and is touched by the shock, as is the little heap of magnesium powder by the flame of the match ([20], pp. 632-633).

I have passed these buildings at the top of Ouellette for years, experiencing them only through "the half-light of habit” ([20], p. 632). Now, seeing Paris in Windsor, I am transported back to a version of myself I thought lost for good. As a graduate student, I spent years looking at the Paris photograph. This was before I felt the dominion of University Disciplines and the internecine wars between faculty members. Before I abandoned my lifelines-Bataille, Benjamin, Derrida, Freud, Kristeva_-because they seemed improper to my academic context, and before the writer's block took up residence.

7 Mukhina designed the sculpture, Worker and Kolkhoz Woman, which tops Iofan's pavilion. 
When I was first hired and preparing the move east, my boyfriend looked for a guidebook on Detroit. None existed. Finally, in a Let's Go USA from 2003, he found a few pages dealing with the city. ${ }^{8}$ One of the suggested excursions was a trip across the river to Windsor. Detroit is, after all, also a place to leave. From the book: "Combining cultural highlights, natural attractions, and a vibrant nightlife, Windsor offers tourists an alternative to the industrial city across the river. Outdoor cafes, tree-filled streets, and lively shopping give Windsor a pleasant European feel” ([22], p. 539). At the time, I doubted whether the author had ever visited Windsor, or Europe for that matter. Yet now I see the Eiffel Tower haunting the top of Ouellette, and I think that Benjamin might be just around the corner, walking up Pelissier, trying to decide which strip club to enter.

Albert Speer and Boris Iofan and the invisible Spanish Pavilion bring me a feeling of homey-ness. In the foreign space of Windsor, with its O-lets and its Peerees, I grab hold of a connecting wire to an earlier version of me. Benjamin conceives history in imagistic terms. His famous description of dialectics at a standstill defines image as "that wherein what has been comes together in a flash with the now to form a constellation” ([16], p. 462). The constellation inaugurates new patterns of thought, new modes of perception. It makes writing possible. As Paris seeps into Windsor, the uncanny is activated.

\section{Acknowledgments}

I am grateful to Patrick Fowlow, Graeme Gilloch, and Allen Shelton for helping me along as I think about the connections between built environments and writing.

\section{Conflicts of Interest}

The author declares no conflict of interest.

\section{References and Notes}

1. Brandt, D. Now You Care; Coach House Books: Toronto, Canada, 2003.

2. Scott, R., Dir. Alien [film]; Brandywine Productions: Salt Lake City, UT, USA, 1979.

3. Simmel, G. On Individuality and Social Forms; Selected Writings; University of Chicago Press: Chicago, IL, USA, 1971.

4. Windsor Hum. Available online: http://www.youtube.com/watch?v=tPDILKQjJW8 (accessed on 10 November 2013).

5. Taussig, M. The Nervous System; Routledge: New York, NY, USA, 1992.

6. Gary Grosse spent thousands of hours trying to stop the 'Windsor Hum'. Available online: http://news.nationalpost.com/2013/01/21/resident-devoted-thousands-of-hours-to-stoppingmysterious-windsor-hum-that-is-loud-enough-to-drive-you-insane/ (accessed on 10 November 2013).

7. Barthes, R. Empire of Signs; Hill and Wang: New York, NY, USA, 1982.

8. Yeats, W.B. Collected Poems; W.B. Yeats; Collector's Library: London, UK, 2010.

9. Binelli, M. Detroit City is the Place to Be: The Afterlife of an American Metropolis; Metropolitan Books: New York, NY, USA, 2012.

8 In 2012, the first guidebook devoted to Detroit was published: [21]. 
10. Herron, J. Afterculture: Detroit and the Humiliation of History; Wayne State University Press: Detroit, MI, USA, 1995.

11. LeDuff, C. Detroit: An American Autopsy; Penguin: New York, NY, USA, 2013.

12 Solnit, R. Detroit Arcadia: Exploring the Post-American Landscape. Harper's Magazine 2007, 315, 65-73.

13. Marchand, Y.; Meffre, R. Yves Marchand and Romain Meffre Photography: The Ruins of Detroit. Available online: http://www.marchandmeffre.com/detroit/ (accessed on 15 November 2013).

14. Boileau, L. Fabulous Ruins of Detroit. Available online: http://detroityes.com/fabulous-ruins-ofdetroit/home.php (accessed on 15 November 2013).

15. Latour, B. Reassembling the Social: An Introduction to Actor-Network Theory; Oxford University Press: Oxford, UK, New York, NY, USA, 2005.

16. Benjamin, W. The Arcades Project; Harvard University Press: Cambridge, MA, USA, 1999.

17. Wood, P, Ed. Art in Theory; Blackwell: Malden, MA, USA, 2003.

18. Musil, R. Posthumous Papers of a Living Author; Archipelago Books: Brooklyn, NY, USA, St. Paul, MN, USA, 2006.

19. Derrida, J. Of Grammatology; Johns Hopkins University Press: Baltimore, MY, USA, 1976.

20. Benjamin, W. Walter Benjamin: Selected Writings, Volume 2: Part 2: 1931-1934; Jennings, M., Smith, G., Eiland, H., Eds.; Harvard University Press: Cambridge, MA, USA, 2005.

21. Linn, A., Linn, E., Linn, R., Eds. Belle Isle to 8 Mile: An Insider’s Guide to Detroit; Detroit, MI, USA, 2012.

22. Farrell, B. USA 2003: Including Coverage of Canada; St. Martin’s Press: New York, NY, USA, 2003.

(C) 2013 by the author; licensee MDPI, Basel, Switzerland. This article is an open access article distributed under the terms and conditions of the Creative Commons Attribution license (http://creativecommons.org/licenses/by/3.0/). 